\title{
Olahraga Bagi Wanita Hamil
}

Oleh: Yudik Prasetyo

Dosen Jurusan Pendidikan Kesehatan dan Rekreasi FIK UNY

\section{Abstrak}

Sehat merupakan dambaan setiap wanita yang sedang hamil. Selain makanan, olah raga merupakan salah satu cara untuk memperoleh keadaan sehat. Wanita hamil harus memastikan untuk selalu mengasup kalori dari makananmakanan bergizi agar dapat menunjang pertumbuhan dan perkembangan bayi. Kebutuhan asupan gizi ibu hamil secara umum dalam masa kehamilan yaitu: kalori, protein, vitamin, dan mineral.

Olahraga yang aman dilakukan oleh wanita hamil adalah jalan kaki, senam hamil, dan renang. The Canadian Society for Exercise Physiology and Society of Obstetricians and Gynecologists of Canada memberikan rekomendasi untuk wanita hamil berumur kurang dari 20 tahun, detak jantung maksimal antara 140-155. Untuk wanita hamil berusia antara 20-29 tahun, detak jantung maksimal yaitu 135-150 sedangkan bagi wanita hamil berusia 30-39 tahun detak jantung maksimalnya 130-145. Bagi ibu hamil yang berusia lebih dari 40 tahun, detak jantung maksimal saat berolah raga yaitu 125-140. Olahraga secara umum memberi banyak manfaat bagi wanita hamil yaitu: (1) menguatkan otot, (2) menjaga kelancaran kerja jantung dan peredaran darah, (3) membantu berjalan tegak, (4) membantu persalinan, 
memiliki daya tahan tubuh setelah melahirkan, (6) mengurangi selulit, (7) memperbaiki kulit tubuh, (8) mengurangi stres, (9) membantu menurunkan risiko pre-eklampsia, dan (10) memperlancar ASI.

Kata kunci: Olahraga, wanita, hamil

Kehamilan merupakan suatu peristiwa yang penting dalam kehidupan seorang wanita dan keluarga pada umumnya. Walaupun perubahan yang besar yang akan terjadi sangat mempengaruhi semua orang. Kehamilan juga dapat diartikan saat-saat krisis, saat terjadi gangguan dan perubahan identitas serta peran bagi setiap anggota keluarga. Manusia berespon terhadap krisis tersebut dengan cara yang berbeda setiap individu sesuai dengan sifat kejadian yang ada dalam kehidupannya. Kehamilan sangat mempengaruhi perubahan fisiologis dalam tubuh ibu secara keseluruhan yang pada hakekatnya terjadi pada semua organ terutama pada organ reproduksinya yang menjadi pusat perhatian selama masa kehamilan.

Pada masa kehamilan, sehat merupakan dambaan setiap wanita yang sedang hamil. Selain makanan, olah raga merupakan salah satu cara untuk memperoleh keadaan sehat tersebut. Namun, masih banyak wanita hamil yang takut untuk berolah raga, mereka khawatir olah raga bisa menyebabkan gangguan pada kehamilan. Pada umumnya,

MEDIKORA Vol. IV, No 1, April 2008: 150-175 
olah raga aman dilakukan saat hamil. Beberapa olah raga yang dianjurkan atau diperbolehkan pada masa kehamilan yaitu aerobik, jalan jalan, berenang, senam air, menari, bersepeda statis, dan yoga. Setiap wanita hamil mempunyai karakteristik yang berbeda beda sehingga olah raga yang dipilih harus disesuaikan dengan keadaan si ibu hamil.

Wanita hamil mewakili klien yang unik karena kemungkinan persaingan dalam aliran darah, pengangkutan oksigen, ketersediaan glukosa, dan pembuangan panas antara otot ibu yang berlatih dengan janin. Selain itu, adaptasi metabolik dan kardiorespiratorik pada kehamilan bisa mengubah respons terhadap latihan akut dan adaptasi akibat latihan olah raga. Manfaat program latihan prenatal yang dirancang tepat meliputi: perbaikan kebugaran otot dan aerobik, fasilitas penyembuhan setelah melahirkan, peningkatan keadaan psikologis ibu,dan pembinaan kebiasaan hidup sehat secara permanen. (Djaja Surya Atmadja dan Muchsin Doewes, 2004: 202).

\section{Pola Makan Selama Kehamilan}

Makanan sehat adalah hal yang penting, terutama saat hamil. Seorang wanita hamil harus memastikan untuk selalu mengasup kalori dari makanan-makanan bergizi agar dapat menunjang pertumbuhan dan perkembangan bayi. Usahakan 
mengkonsumsi makanan sehat seimbang yang tergabung dalam dietary guidelines, yaitu: daging tanpa lemak, buahbuahan, saytur-sayuran, roti gandum, produk susu (dairy products) rendah lemak. Selain itu, dokter juga akan memberikan vitamin-vitamin kehamilan agar wanita hamil dan bayi mendapatkan vitamin yang cukup. Vitamin kehamilan dimaksudkan sebagai penambah nutrisi, bukan merupakan satu-satunya sumber nutrisi yang dibutuhkan (Djoko Pramono, 2008: http://karawang.info/? $\mathrm{p}=729$, download on January 14, 2008.).

Menurut Tomi, kebutuhan asupan gizi ibu hamil secara umum dalam masa kehamilannya dapat diuraikan sebagai berikut:

1. Kalori. Zat ini dibutuhkan untuk pembentukan sel-sel baru, pengaliran makanan dari pembuluh darah ibu ke pembuluh darah janin melalui plasenta, serta pembentukan enzim dan hormon yang mengatur petumbuhan janin. Kalori ini diperlukan juga bagi tubuh si ibu itu sendiri untuk dapat berfungsi secara baik. Berapa jumlah yang dibutuhkan? Umumnya selama masa kehamilan 6 bulan pertama tidak terdapat peningkatan kebutuhan yang bermakna dari kondisi pada saat si ibu tidak hamil. Peningkatan kebutuhan sekitar 200 Kalori perhari diperlukan saat usia

MEDIKORA Vol. IV, No 1, April 2008: 150-175 
kehamilan antara 6-9 bulan. 200 Kalori tersebut dalam keseharian dapat diwakilkan dengan 1 toast sandwich keju.

2. Protein yang banyak terdapat pada daging, keju, ikan, telur, kacang-kacangan, tahu dan tempe, berguna untuk membangun sel-sel baru janin (sel darah, kulit, rambut, kuku, dan jaringan otot). Protein buat sang Ibu juga memiliki fungsi sama yaitu sebagai zat pembangun. Kebutuhan selama kehamilan tidak jauh berbeda dengan saat sebelum hamil. Bagi wanita asia umumnya, usia 19-49 tahun perhari diperlukan protein sebanyak 50 Gram. Pembagian lebih rinci 50 Gram tersebut menurut sumber proteinnya adalah 9 Gram protein ikan, 6 Gram protein hewan dan antara 35-40 Gram dari sumber nabati/tumbuhan.

3. Vitamin. Banyak jenis vitamin diperlukan selama kehamilan dalam jumlah tertentu daintaranya : Vitamin A untuk pertumbuhan janin yang dibutuhkan dalam jumlah tertentu saja dan tidak berlebihan karena dapat berbahaya bagi kesehatan janin. Sangat dianjurkan untuk menkonsumsi vitamin A yang bersumber dari sayur dan buah-buahn seperti mangga, tomat, wortel dan aprikot. Sumber-sumber vitamin A lainnya masih sangat banyak dan dapat ibu Ria telusuri dengan mudah; vitamin B1 dan B2 
serta niasin untuk proses metabolisme tubuh; Vitamin B6 dan B12 untuk mengatur penggunaan protein; Vitamin C untuk membantu penyerapan zat besi selama hamil atau mencegah anemia; Vitamin D pada susu dan olahannya serta kacang-kacangan, menopang pembentukan tulang, gigi, serta persendian janin dan Vitamin $\mathrm{E}$ untuk pembetukan sel-sel darah merah serta melindungi lemak dari kerusakan.

4. Mineral, asam folat dan seng dalam sayuran dan buahbuahan seperti jeruk, pisang, brokoli, serta wortel untuk pembentukan susunan saraf pusat dan otak janin. Kedudukan mineral disini sangat penting berkaitan karena mineral juga membantu proses tumbuh kembang organ bayi.

Penting juga untuk diingat bahwa selama kehamilan kenaikan berat badan ibu dapat menjadi penentuan kecukupan gizi. Walaupun tidak langsung berkaitan dengan berat badan janin yang dilahirkan, akan tetapi biasanya seorang ibu hamil yang sehat dapat mengalami kenaikan berat badan selma kehamilan sebesar 8-15 Kg yang bervariasi menurut pola individual tergantung pada berat badan sebelumya, ras, usia dan pola makan (Tomi,

MEDIKORA Vol. IV, No 1, April 2008: 150-175 
http:/ / www.forkom-jerman.org/index.php?option=com download on January 14, 2008).

Pemberian suplementasi pil zat besi pada wanita hamil menjadi salah satu yang dapat dilakukan untuk mencegah terjadinya anemia. Disarankan minum pil zat besi ini selama tiga bulan awal kehamilan, setiap harinya. Penelitian menunjukan, wanita hamil yang tidak minum pil zat besi mengalami penurunan cadangan besi cukup tajam sejak minggu ke-12 usia kehamilan. Tetapi, cara ini memberikan efek samping mual, diare, dan lainnya. Maka, alternatifnya adalah mengkonsumsi makanan yang diperkaya dengan zat besi, misalnya berbentuk susu atau roti. Penderita anemia ringan sebaiknya tidak menggunakan suplemen besi, lebih tepat bila mereka mengupayakan perbaikan menu makanan. Misalnya, dengan meningkatkan konsumsi makanan yang mengandung zar besi seperti telur, susu, hati, ikan, daging, kacang-kacangan (tempe, tahu, oncom, kedelai, kacang hijau), sayuran berwarna hijau tua (kangkung, bayam, daun katuk), dan buah-buahan (jeruk, jambu biji, pisang). Biasakan pula menambahkan substansi yang memudahkan penyerapan zat besi seperti vitamin C, air jeruk, daging, ayam, dan ikan. Sebaliknya, substansi penghambat 
penyerapan zat besi seperti teh dan kopi perlu dihindari (Maya Lestari Widyastuti, 2007: 52).

Pada Sebagian besar wanita berusi 19 tahun atau lebih - termasuk yang sedang hamil - tidak selalu mendapatkan $1,000 \mathrm{mg}$ kalsium harian yang disarankan. Kebutuhan kalsium yang tinggi untuk pertumbuhan bayi, maka wanita hamil perlu menambah konsumsi kalsium untuk mencegah tulang kehilangan kalsiumnya. Sumber-sumber kalsium: susu dan dairy products yang rendah lemak (seperti keju dan yogurt), produk calcium-fortified (termasuk jus jeruk, susu kedelai dan sereal), sayur-sayuran berwarna hijau gelap (seperti bayam, kale dan brokoli), tofu, kacang-kacangan yang dikeringkan, almond.

The U.S. Centers for Disease Control and Prevention (CDC) merekomendasikan bahwa semua wanita yang sedang hamil - dan terutama bagi wanita yang sedang merencanakan kehamilan - mengkonsumsi sekitar 400 micrograms $(0.4 \mathrm{mg})$ suplemen folic acid (folate) setiap harinya, yang bisa didapat dari multivitamin atau suplemen folic acid sebagai penambah folic acid yang didapat dari makanan. Hasil studi menunjukkan bahwa dengan mengkonsumsi suplemen folic acid sejak 1 bulan sebelum dan selama 3 bulan pertama kehamilan dapat mengurangi resiko neural tube defects

MEDIKORA Vol. IV, No 1, April 2008: 150-175 
hingga $70 \%$. The neural tube, yang nantinya akan menjadi otak dan urat saraf tulang belakang bayi, terbentuk saat 28 hari pertama saat kehamilan, dimana biasanya wanita tersebut belum menyadari bahwa dirinya tengah hamil. Jika neural tube tidak terbentuk dengan baik akan menyebabkan neural tube defect seperti spina bifida. Beberapa penyedia layanan kesehatan kehamilan merekomendasikan untuk mengkonsumsi suplemen folic acid tambahan, terutama bagi wanita yang telah memiliki anak dengan neural tube defect (Djoko Pramono, 2009: http://karawang.info/? p=729, download on January 14, 2008.).

\section{OLAHRAGA BAGI WANITA HAMIL}

Semua orang tahu olahraga merupakan cara yang baik untuk memelihara stamina tubuh. Ternyata, bagi wanita hamil, olahraga juga mempunyai banyak manfaat. Sebuah penelitian baru mengungkapkan bahwa saat seorang calon ibu bekerja atau melakukan aktivitas fisik, janinnya akan mendapatkan efek, yakni jantung si janin makin kuat dan sehat. Setidaknya irama jantung tidak berdetak kencang, melainkan melambat teratur. Demikian diungkapkan dalam pertemuan tahunan Experimental Biology 2008 di San Diego. "Penelitian ini menyatakan bahwa seorang ibu yang 
melakukan aktivitas fisik tidak hanya mendapatkan manfaat bagi jantungnya sendiri, tetapi juga bermanfaat bagi jantung si janin. Séperti hasil penelitian rintisan yang sudah dilakukan, Linda E. May, dari Department of Anatomy di Kansas City University of Medicine and Biosciences melanjutkan penelitian yang melibatkan banyak wanita hamil. Sepuluh orang wanita berpartisipasi dalam penelitian itu, separuhnya melakukan aktivitas fisik yang lain tidak. Gerakan janin seperti bernapas, gerak tubuh dan mulut dimonitor dan direkam selama 24 minggu. Para peneliti menemukan melambatnya irama jantung secara berarti yang terjadi selama para ibu melakukan aktivitas fisik. Sementara irama jantung janin pada para ibu yang tidak banyak beraktivitas justru lebih tinggi (http://www.kompas.com/read/xml/2008/04/09/23014124 L, download on January 18, 2008.).

Detak jantung wanita hamil saat berolah raga dianjurkan untuk tidak melebihi 140 kali per menit. Tetapi rekomendasi ini masih menjadi bahan perdebatan karena sedikit sekali bukti-bukti yang mendukung. Beberapa penelitian menunjukan peningkatan detak jantung sampai $70 \%$ dari normal tidak akan menganggu atau mempengaruhi detak jantung pada bayi dalam kandungan. The Canadian

MEDIKORA Vol. IV, No 1, April 2008: 150-175 
Society for Exercise Physiology and Society of Obstetricians and Gynecologists of Canada memberikan rekomendasi sebagai berikut : Untuk wanita hamil yang berumur kurang dari 20 tahun, detak jantung maksimal antara 140-155. Untuk ibu hamil yang berusia antara 20-29 tahun, detak jantung maksimalnya yaitu 135-150 sedangkan bagi ibu hamil yang berusia 30-39 tahun detak jantung maksimalnya 130-145. Terakhir bagi ibu hamil yang berusia lebih dari 40 tahun maka detak jantung maksimal saat berolah raga yaitu 125140

(http://romisepsrizal.multiply.com/journal/item/199/Olah_R aga_Bagi_Ibu_, download on January 23, 2008).

Olahraga bagi wanita hamil harus dilakukan hati-hati sesuai anjuran dokter maupun pakar olahraga. Anjuran latihan pada kehamilan dan postpartum dari American College Of Obstetricians And Gynecologist (ACOG) adalah sebagai berikut:

1. Selama kehamilan, wanita bisa terus melakukan latihan dan memperoleh keuntungan kesehatan bahkan dari latihan rutin yang ringan sampai yang sedang. Latihan yang teratur secara intermiten(paling tidak 3 kali per minggu) sangat diutamakan 
2. Wanita sebaiknya menghindari latihan dalam posisi terlentang setelah tri semester yang pertama. Posisi semacam itu menyebabkan penurunan curah jantung pada sebagian besar wanita. Karena curah jantung yang tetap akan didistribusikan keluar dari organ splanknik (termasuk uterus) selama latihan yang berat, hal tersebut sebaiknya dihindarkan selama masa kehamilan. Periode berdiri diam tanpa bergerak dalam waktu lama juga harus dihindarkan

3. Wanita harus waspada terhadap penurunan ketersediaan oksigen saat latihan aerobik selama masa kehamilan. Mereka harus didorong untk memodifikasi intensitas latihan menurut gejala maternal. Wanita hamil harus berhenti berlatih jika lelah dan tidak berlatih sampai kehabisan tenaga. Latihan beban dapat dilanjutkan menurut kondisi-kondisi tertentu pada intensitas yang sama dengan sebelum kehamilan. Latihan tanpa beban, seperti bersepeda atau berenang, akan mengurangi risiko cedera dan memfasilitasi kelanjutan latihan selama kehamilan

4. Perubahan-perubahan morfologis dalam kehamilan merupakan kontraindikasi relatif untuk jenis-jenis latihan yang menyebabkan kehilangan keseimbangan karena

MEDIKORA Vol. IV, No 1, April 2008: 150-175 
dapat merugikan keadaan ibu atau janin, khususnya dalam trismester ketiga. Oleh karena itu, semua jenis latihan yang dapat menyebabkan trauma perut meskipun ringan harus dihindari

5. Kehamilan membutuhkan 300 kkal/hari untuk mempertahankan homeostatis metabolik. Wanita yang melakukan olahraga selama kehamilan harus berhati-hati untuk menjamin kecukupan diet

6. Wanita hamil yang berlatih trisemester pertama harus memperbeasr pengeluaran panas dengan menjamin hidrasi yang cukup, pakaian yang sesuai, dan lingkungan yang optimal selama olahraga

7. Banyak perubahan-perubahan fisiologis maupun morfologis pada kehamilan yang berlangsung sampai empat sampai enam minggu postpartum. Latihan rutin sebelum kehamilan harus dilanjutkan secara bertahap berdasarkan pada kemampuan fisik wanita tersebut

(Djaja Surya Atmadja dan Muchsin Doewes, 2004: 203)

Wanita hamil yang berolahraga secara teratur mengalami kenaikan berat dan lemak tubuh yang lebih sedikit dibandingkan wanita yang kurang aktif. Berat badan tetap naik dengan normal dan bayi tetap dalam kondisi kesehatan yang prima. Selain itu, kehamilan dan proses 
persalinan wanita aktif cenderung tidak bermasalah. Apabila kehamilan mempengaruhi keseimbangan tubuh, maka jalan kaki adalah olahraga yang paling tepat bagi seorang wanita hamil. Pada waktu hamil, olahraga dapat menguatkan otot dan melindungi persendian serta tulang belakang. Dengan berolahraga, tuntutan masa kehamilan pada tubuh dapat terpenuhi dengan baik (Maya Lestari Widyastuti, 2007: 53).

Jalan kaki adalah salah satu latihan fisik terbaik untuk menyehatkan pembuluh jantung ibu hamil, karena tidak terlalu membebani lutut dan persendian. Manfaat lainnya yaitu: mengurangi stres fisik. Mark Fenton, rekan-penulis Walking Through Pregnancy and Beyond: How Expectant Moms Can Walk Through a Happy and Healthy Pregnancy and First Year menyebutkan, jalan kaki kegiatan ideal selama hamil karena tidak membuat tubuh ibu stres akibat latihan fisik yang tidak biasa. Menurut Kelli Calabrese, pakar kebugaran dan kepala pelatih di pusat kebugaran online ediets.com, stres fisik juga bisa berkurang jika ibu tetap aktif selama hamil. Sedangkan Ann W. Wright, assistant professor bidang biologi di Canisius College, AS yang juga ahli fisiologi latihan fisik khusus selama kehamilan mengungkapkan, jalan kaki membantu ibu hamil tidur lebih nyenyak, karena latihan fisik melepaskan endorfin yang membantu ibu hamil rileks

MEDIKORA Vol. IV, No 1, April 2008: 150-175 
(http://naya.web.id/2007/08/08/jalan-kaki-tak-hanyalancarkan-persalinan/, download on January 23, 2008)

Senam hamil adalah adalah terapi latihan gerak untuk mempersiapkan ibu hamil, secara fisik atau mental, pada persalinan cepat, aman dan spontan. Jenis olah tubuh yang paling sesuai untuk ibu hamil adalah senam hamil, disesuaikan dengan banyaknya perubahan fisik seperti pada organ genital, perut kian membesar dan lain-lain. Dengan mengikuti senam hamil secara teratur dan intensif, ibu hamil dapat menjaga kesehatan tubuh dan janin yang dikandung secara optimal. Pada ibu hamil sangat dibutuhkan tubuh yang sehat dan bugar, diupayakan dengan makan teratur, cukup istirahat dan olah tubuh sesuai takaran. Dengan tubuh bugar dan sehat, ibu hamil tetap dapat menjalankan tugas rutin sehari-hari, menurunkan stres akibat rasa cemas yang dihadapi menjelang persalinan. Sebelum memulai senam hamil, lakukan dulu gerakan pemanasan sehingga peredaran darah dalam tubuh akan meningkat dan oksigen yang diangkut ke otot-otot dan jaringan tubuh bertambah banyak, serta dapat mengurangi kemungkinan terjadinya kejang/luka karena telah disiapkan sebelumnya untuk melakukan gerakan yang lebih aktif. Perempuan mengandung yang mengikuti senam hamil diharapkan dapat menjalani 
persalinan dengan lancar, dapat memanfaatkan tenaga dan kemampuan sebaik-baiknya sehingga proses persalinan normal berlangsung relatif cepat. Kapan dianjurkan mengikuti senam hamil? Jika kandungan mencapai 6 bulan ke atas, lakukan senam hamil, kecuali ada kelainan tertentu pada kehamilan. Sebelum memutuskan mengikuti senam hamil, diskusikan kondisi kehamilan dengan dokter atau bidan (http://www.tipsmanfaat.com/manfaat-senamhamil.html, download on January 23, 2008).

Posisi dasar senam hamil yaitu berbaring diatas punggung, tekuk kedua lutut keatas, rentangkan kedua kaki selebar $30 \mathrm{~cm}$ (12 inci), menapak rata di atas lantai. Kepala dan pundak sebaiknya ditopang dengan bantal, kedua tangan terletak rata di lantai di samping tubuh. Posisi senam ini hanya sampai bulan keempat. Setelah itu, senam dengan tubuh rata diatas lantai tidak dianjurkan lagi, karena rahim yang membesar akan sangat membebani pembuluhpembuluh darah utama.

- Latihan Kegel

MEDIKORA Vol. IV, No 1, April 2008: 150-175 
Kencangkan dengan kuat otot-otot vagina dan anus. Tahanlah selama mungkin (sekitar 10 detik) lalu lemaskan perlahanklahan. Setelah bulan ke-4 lakukan latihan ini dalam posisi berdiri atau duduk. Lakukan kurang lebih 25 kali sehari.

- Memiringkan Panggul

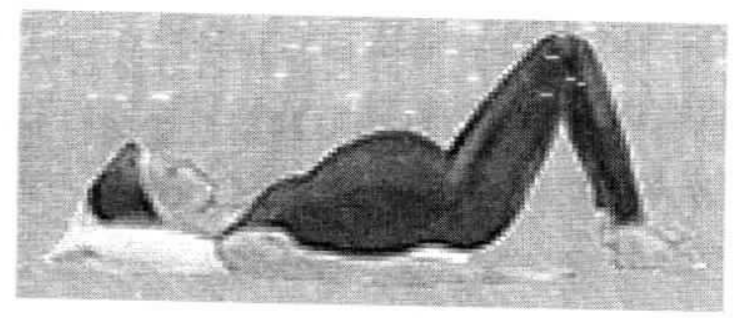

Hembuskan napas saat menekan lekuk punggung ke lantai. Tarik napas dan lemaskan punggung anda. Ulangi 3 atau 4 kali. Latihan ini bisa juga dilakukan sambil berdiri menyandar di dinding. Tarik nafas pada waktu menekan lekuk punggung ke dinding. Posisi berdiri sangat baik untuk memperbaiki postur tubuh dan sebaiknya dilakukan setelah bulan ke-4.

- Mengangkat kaki

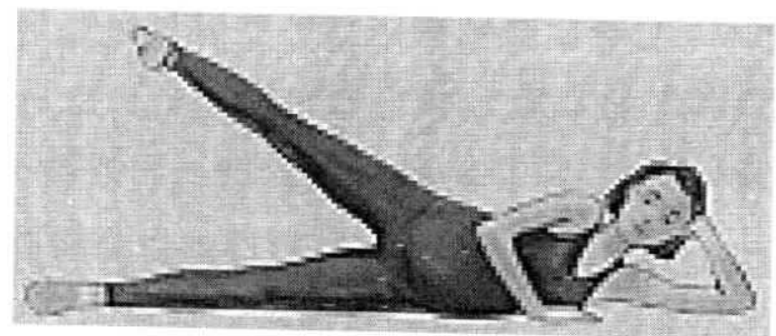


Berbaring miring ke kiri dengan pundak, pinggul, dan lutut dalam satu garis lurus. Telapak tangan kanan menapak lantai di depan dada, dan topang kepala dengan tangan kiri. Rileks, tarik napas, lalu hembuskan perlahan-lahan sambil mengangkat kaki kanan setinggi mungkin, punggung kaki melentur (jari-jari kaki menunjuk kearah perut anda) dan mata kaki sebelah dalam menghadap ke lantai. Ulangi 10 kali untuk setiap sisi. Lutut dari kaki yang diangkat boleh lurus atau menekuk.

- Menunduk seperti unta

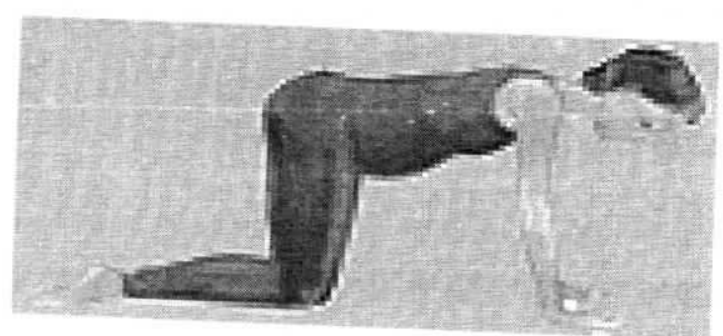

Membungkuk bertekan pada lutut dan tangan dengan punggung rileks seperti biasa, tulang punggung jangan melengkung kebawah. Angkat kepala, leher lurus dengan tulang punggung. Kemudian bungkukkan punggung, kencangkan perut dan pantat, lalu jatuhkan kepala sejauh mungkin. Kembalikan punggung dan kepala perlahan-lahan ke posisi awal. Ulangi 3 atau 4 kali. Latihan ini amat membantu mengatasi tekanan pada tulang punggung yang disebabkan oleh pembesaran rahim (uterus).

MEDI KORA Vol. IV, No 1, April 2008: 150-175 
- Duduk meregang tangan

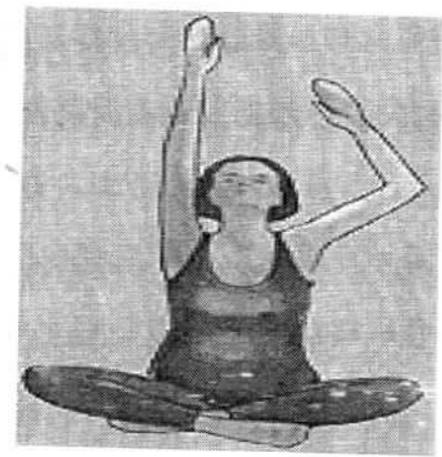

Duduk bersila dengan nyaman. Seringlah duduk bersila lalu lakukan peregangan tangan. Peganglah pundak lalu rentangkan kedua tangan keatas kepala seolah ingin meraih langit-langit, yang satu lebih tinggi dari yang lain. Lakukan yang sama untuk tangan satunya. Tangan jangan disentaksentak. Ulangi 10 kali.

- Melemaskan leher

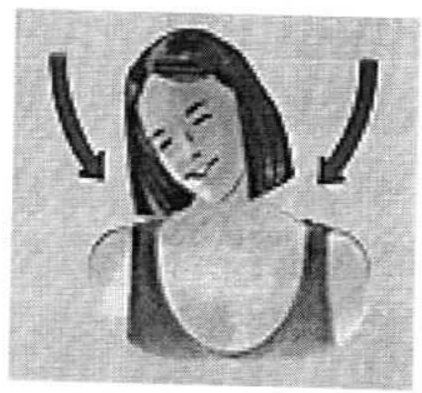

Leher seringkali terasa kaku. Latihan ini membantu melemaskan leher dan seluruh tubuh. Duduk bersila sambil memejamkan mata. Tarik napas pelan-pelan, putar kepala setengah lingkaran perlahan-lahan. Buang napas, rileks, lalu 
tundukkan kepala. Ulangi 4 sampai 5 kali, berganti-ganti arah. Lakukan 3 sampai 4 kali sehari (Wyeth Nutrition, http://www wyethindonesia.com/\$\$Olahraga.html, download on January 28, 2008)

Olahraga secara umum memberi banyak manfaat bagi wanita hamil, diantaranya sebagai berikut:

1. Menguatkan otot

Kehamilan mengakibatkan beberapa otot tubuh menjadi lemah. Kondisi ini dapat diperkuat dengan latihan. Tanpa latihan apa pun, anda akan merasakan sakit di bagian tubuh lain. Misalnya, jika otot-otot perut anda kurang kuat, maka otot pinggang anda harus bekerja ekstra untuk menahan tulang belakang. Olahraga perlu dilakukan untuk menyeimbangkan kekuatan otot-otot tubuh.

2. Menjaga kelancaran kerja jantung dan peredaran darah Dengan berolahraga, sirkulasi darah dalam tubuh berjalan lancar. Hal ini mengakibatkan tubuh bisa lebih efisien "memompa" oksigen untuk memenuhi kebutuhan janin. Selain itu, sirkulasi darah yang lancar akan mencegah terjadinya varises (pelebaran pembuluh darah).

3. Membantu berjalan tegak

Seiring dengan bertambahnya usia kehamilan maka beban tubuh anda juga semakin berat. Akibatnya, keseimbangan

MEDIKORA Vol. IV, No 1, April 2008: 150-175 
badan berubah dan berpusat diperut, sehingga pada saat berjalan, anda cenderung "membuang badang" ke depan atau ke belakang. Artinya, sikap tersebut melawan daya tarik bumi. Padahal kedua sikap tubuh yang salah tersebut akan membuat pinggang anda sakit. Dengan berolahraga, gangguan tersebut bisa dihindari.

4. Membantu persalinan

Para ahli mengungkapkan, otot-otot tubuh yang "terbentuk" dan kuat, cenderung membuat persalinan lebih cepat dan mudah. Itulah sebabnya, mereka yang secara rutin berolahraga sepanjang kehamilannya, lebih kecil kemungkinanya mengalami operasi caesar. Kekuatan dan stamina mereka lebih baik, sehingga mereka mempu mengendalikan konsentrasi saat melahirkan.

5. Memiliki daya tahan tubuh setelah melahirkan

Setelah melalui proses persalinan yang sangat melelahkan , anda masih harus merawat bayi anda. Dengan kebiasaan berolahraga, anda akan memiliki lengan dan punggung yang kuat. "Modal" anda yang satu ini besar manfaatnya saat anda menggendong dan mengangkat si kecil.

6. Mengurangi selulit

Olahraga secara teratur mengurangi risiko terkena selulit (lemak yang bentuknya seperti kulit jeruk dan berkerut 
disekitar pinggang dan paha). Perubahan hormonal dalam tubuh, sirkulasi darah yang buruk, dan tidak aktifnya fisik merupakan pemicu terbentuknya selulit.

7. Memperbaiki kulit tubuh

Olahraga pada dasarnya membantu meningkatkan sirkulasi darah, sehingga akan memperbaiki bentuk dan warna kulit anda. Kulit wajah anda akan bersinar dan lebih sehat, sementara kulit tubuh menjadi lebih sehat dan lentur. Manfaat olahraga yang lainnya adalah memperkecil kemungkinan timbulnya guratan-guratan bekas kehamilan

8. Mengurangi stres

Ibu hamil biasanya rentan terhadap stres. Stres ini dikhawatirkan dapat meningkatkan risiko kelahiran prematur. Berolahraga akan memicu keluarnya hormon endorfin, yaitu hormon yang membuat Anda merasa senang atau bahagia.

9. Membantu menurunkan risiko pre-eklampsia

Olahraga selama kehamilan terbukti dapat menurunkan risiko pre-eklampsia (keracunan dalam kehamilan).

10. Memperlancar ASI

Dengan lancarnya sirkulasi darah, maka bugarlah tubuh Anda. Aliran ASI pun diharapkan lebih lancar lagi. 
(http://dedysubandi.multiply.com/journal/item/82, download on January 14, 2008).

Olłhraga lain yang baik bagi wanita hamil adalah renang. Renang dapat melatih paru-paru dan jantung. Berbeda dengan olahraga darat yang dapat membuat suhu tubuh melonjak atau naik. Ketika berenang, suhu badan ibu stabil sehingga gangguan pada janin akibat meningkatnya suhu tubuh ibu tidak akan terjadi. Renang membantu menguatkan otot-otot rahim dan sendi-sendi panggul, sehingga diharapkan proses melahirkan menjadi lebih mudah. Tetapi yang perlu diperhatikan yaitu jangan sekalipun melakukan gaya punggung, sebab dikhawatirkan akan terjadi penekanan pada pembuluh darah di bagian belakang rahim. Selain itu, juga jangan melakukan gaya kupu-kupu. Gaya ini terlalu banyak melibatkan gerakan pada bagian pinggang sehingga dikhawatirkan akan terjadi benturan pada janin. Olahraga ini dilakukan 3 kali seminggu dan jangan berenang lebih dari 30 menit. Meskipun suhu air dapat menahan kenaikan suhu dalam kandungan, berenang lebih dari 30 menit justru akan meningkatkan suhu dalam kandungan

(http://www.conectique.com/tips solution/pregnancy, download on January 15, 2008). 
Syarat utama bagi ibu hamil yang akan melakukan renang adalah harus melakukan gerakan secara tenang, perlahan-lahan, santai dan jangan ada benturan agar rahim tidak tergoncang. Bagi ibu yang tidak bisa berenang, cukup melakukan gerakan berjalan di kolam renang yang dangkal atau melakukan gerakan aquarobik (senam aerobik di dalam air). Ibu hamil dianjurkan untuk melakukan gaya bebas dan gaya dada. Pasalnya, kedua gaya tersebut yang paling tenang, perlahan dan tak ada benturan.

\section{KESIMPULAN}

Olah raga jalan kaki, senam hamil, dan renang merupakan aktivitas yang aman dan memberikan banyak manfaat pada masa kehamilan, selama olah raga yang dilakukan disesuaikan dengan kondisi kehamilan dan memperhatikan beberapa hal seperti tersebut diatas. Berkonsultasi ke dokter kebidanan sebelum melakukan olah raga sangat penting dilakukan agar tujuan latihan dapat tercapai sesuai yang diharapkan.

MEDIKORA Vol. IV, No 1, April 2008: 150-175 


\section{DAFTAR PUSTAKA}

Berenang, Olahraga Terbaik Ibu Hamil.

http://www.conectique.com/tips solution/pregnancy/d uring pregnancy/article.php?article id $=4838$, download on January 15, 2008.

Djaja Surya Atmadja dan Muchsin Doewes. (2004). ACSM: Panduan Uji Latihan Jasmani dan Peresapannya. Jakarta: Penerbit Buku Kedokteran EGC.

Djoko Pramono. (2008). Pola Hidup Sehat Dalam Masa Kehamilan. http://karawang.info/?p=729, download on January 14, 2008.

HealthyDay News. (2008). Aktivitas Selama Hamil Bikin Jantung Bayi Sehat. http://www.kompas.com/read/xml/2008/04/09/2301 4124/aktivitas.selama.hamil.bikin.jantung.bayi.sehat, download on January 18, 2008.

http://naya.web.id/2007/08/08/jalan-kaki-tak-hanyalancarkan-persalinan/, download on January 23, 2008

http://www.tipsmanfaat.com/manfaat-senam-hamil.html. (2008). Manfaat Senam Hamil. http://www.kompas.com/read/xml/2008/04/09/2301 4124/, download on January 23, 2008.

Maya Lestari Widyastuti. (2007). Tetap Bugar Ketika Hamil. Jakarta: CV Sportisi Indonesia. 
Olahraga bagi ibu Hamil.

http://romisepsrizal.multiply.com/journal/item/199/O lah Raga Bagi Ibu Hamil, download on January 23, 2008 .

Olahraga Hamil "Siapa Takut"?

http://dedysubandi.multiply.com/journal/item/82, download on January 14, 2008.

Tomi. Pola Makanan Apa yang Cocok Untuk Ibu Hamil 8 Bulan. http://www.forkomjerman.org/index.php?option $=$ com content\&view $=$ articl e\&sid=101:pola-makanan-apa-yang-cocok-untuk-ibuhamil-8-bulan, download on January 14, 2008.

Wyeth Nutrition. (2008). Olahraga.

http://www.wyethindonesia.com/\$\$Olahraga.html?me

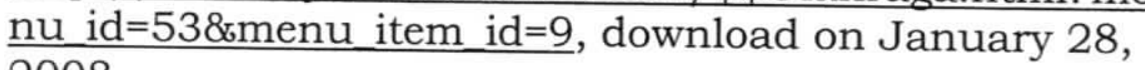
2008. 